\title{
«НЕПЕЧАТНЫЕ» ФОРМЫ ПУБЛИЦИСТИЧЕСКОЙ АКТИВНОСТИ СЛАВЯНОФИЛОВ
}

\section{"UNPRINTED" FORMS OF PUBLICISTIC ACTIVITY OF THE SLAVOPHILES}

\section{Lebedyantsev}

Summary: The article issues institutional aspect of public activity of Russian Slavophiles in the time of Nicolas I. Under conditions of harsh censorship both Slavophiles and Westerners did not have an opportunity of publishing of their polemic articles. In the end, the opponents cannot use neither magazines nor newspapers to spread their views but had to search for other ways to do it. The article research the conclusion that the Slavofiles used the same ways to make their views popular as the Westerners did. From the authors point of view there were three forms of such activities: oral polemic, using the handwritten articles and a "mixed" type.

Keywords: Slavofiles, Westerners, censorship, A. Khomyakov, Y. Samarin.
$\mathrm{B}$ данной статье исследуется институциональный аспект публицистической деятельности славянофилов. Рассматривается вопрос о том, каким образом славянофилы доносили свои идеи до публики, как обходили многочисленные цензурные запреты николаевских времен, какие формы публицистической активности использовали для популяризации своих взглядов.

Исследованию славянофильства посвящено огромное количество исследований. Вместе с тем несмотря на обилие работ о славянофилах, изучению их журналистской, издательской и публицистической деятельности, столкновению с цензурными органами николаевской России исследований посвящено немного.

Первой, наверное, попыткой рассмотрения журналистской деятельности славянофилов стала работа А.Г. Дементьева [6]. Кроме того, Дементьевым было написано несколько глав (гл. XIX-XXI), посвященных журналам 1840-1850-х гг., для первого тома «Очерков по истории русской журналистики и критики» [11, с.437-552]. Однако работы советского исследователя имеют ряд существенных недостатков, которые, скорее всего, являются следствием эпохи. Монография Дементьева была написана в 1951 году и большую часть этого объемного труда составляют идеологические выкладки. Собственно, журналистской деятельности славянофилов Дементьев посвящает лишь несколько страниц. Все остальное - размышления о реакционности их идеологии.
Лебедянцев Иван Михайлович

Преподаватель, ЧОУРО «НЕРПЦ (МП) «Православная гимназия имени Серафима Саровского г. Дзержинска» leb1000.mm@yandex.ru

Аннотация: В статье исследуется институциональный аспект публицистической деятельности славянофилов в годы правления Николая І. В условиях жесткой цензуры николаевских времен, как славянофилы, так и западники были стеснены В возможности публикации своих полемических работ. В итоге обе противоборствующие стороны зачастую вынуждены были использовать для распространения своих взглядов не газеты и журналы, а другие средства массовой коммуникации. Делается вывод, что славянофилы использовали для популяризации своих взглядов те же способы, что и западники. Всего таких форм выделяется три: форма устного диспута, распространение рукописных статей и «смешанная полемика».

Ключевые слова: славянофилы, западники, цензура, А.С. Хомяков, Ю.Ф. Самарин.

Короткие очерки о славянофильской издательской и публицистической деятельности появлялись в монографиях и учебных пособиях по истории отечественной журналистики $[7,15]$.

Важной вехой в исследовании славянофильской публицистики стала работа Т.Ф. Пирожковой «Славянофильская журналистика» [13]. В дальнейшем Т.Ф. Пирожкова защитила докторскую диссертацию по той же теме. На наш взгляд, можно утверждать, что в работах современного исследователя был впервые подробно рассмотрен вопрос публицистической деятельности славянофилов в 1840-1850-х гг. Т. Ф. Пирожкова провела серьезное исследование. Ею в научный оборот впервые были введены ранее не публиковавшиеся документы. Кроме того, исследовательница заполнила важный пробел в исследовании славянофильства, осветив в своей работе жизнь и деятельность одного из ярчайших представителей младшего поколения славянофилов Д.А. Валуева.

Важная роль в исследовании славянофильской издательской деятельности принадлежит В.Н. Грекову, который издал в 2015 г. «Московский сборник» [9], снабдив его комментариями. Кроме первой части сборника, которая увидела свет в 1852 г., он в этом же издании опубликовал вторую часть, не пропущенную в печать цензурою.

Еще одним исследователем, работы которого важны 
для изучаемой нами проблемы, А.И. Виноградов. Опубликованные им в последние несколько лет статьи содержат много важного материалы и ценных наблюдений по вопросам цензуры, столкновения славянофилов и западников, участию членов «московской партии» в деятельности журнала «Москвитянин» $[2,3,4]$.

Кроме этого, небольшого числа исследователей никто всерьез к проблеме взаимоотношения славянофильской журналистики и власти не подходил.

Также и западная историография все свое внимание уделяет учению славянофилов, тогда как институциональный аспект их деятельности не привлекает исследователей. Ценные замечания касательно журналов и публикаций классиков славянофильства мы можем встретить в книге выдающегося исследователя русской философии А. Валицкого [1]. В целом, труды польского ученого представляют собой незаменимый источник для любого исследователя русской общественно-политической мысли, однако вопросы цензуры и печати Валицкий рассматривает эпизодически.

Вместе с тем, вопрос взаимоотношения с цензурными органами и поиск оптимальных форм популяризации своих взглядов стоял перед славянофилами остро и занимал значительное место в их общественной деятельности. В условиях жесткой цензуры и славянофилы, и их оппоненты должны были искать какие-то иные формы публицистической активности для того, чтобы доносить и популяризировать свои идеи. Причем для славянофилов этот вопрос стоял острее, чем для западников, журналистская судьба которых была более успешной. И в 1830-х, и в 1840-х годах, и даже в период «Мрачного семилетия» (1848-1855 гг.) западники имели собственные печатные органы. Некоторые из западнических журналов находились под непосредственной, хотя и тайной, «опекой» правительства, как, например, «Отечественные записки» Краевского. У славянофилов такого издания не было. Как отмечает известный польский исследователь славянофильства А. Валицкий, между славянофилами и западниками «публичных полемик было сравнительно мало - в частности, потому, что в сороковые годы славянофилы не имели собственного регулярно выходящего печатного органа и главные свои труды опубликовали лишь в пятидесятые годы» [1, с.512].

Они могли рассчитывать только на публикации в «Москвитянине», но этот журнал, конечно, нельзя назвать славянофильским. Иногда критике сотрудников «Москвитянина» подвергались статьи и славянофилов. Так, например, было со статьей А.С. Хомякова «О сельских условиях» 1842 г. [20], на которую последовал ответ в восьмом номере журнала за этот же год [10]. Похожая ситуация была со знаменитой статьей Ю.Ф. Самарина «О мнениях «Современника» литературных и историче- ских» [16]. Вскоре после публикации на страницах того же самого «Москвитянина» появилась критика этой статьи. Это особенно важно, если учесть, что Самарин писал свою статью как ответ «Современнику» - главному литературному антагонисту «Москвитянина». Этих примеров достаточно, чтобы показать, насколько редакция «Москвитянина» была далека от безоговорочной поддержки славянофильства.

В ходе своей полемики с западниками славянофилы вынуждены были выработать иные, непечатные формы публицистической активности, которые были бы неподотчетны цензурным ведомствам. Такие «нецензурные» формы борьбы использовали и западники, так же как и их оппоненты, страдавшие от прессинга николаевской идеологической машины.

Первый из таких видов массовой коммуникации были диспуты в салонах и на литературных вечерах. Славянофилы и западники собирались на вечерах у Свербеевых, Елагиных и во многих других домах. Там часто завязывались нешуточные словесные баталии. Особенно знаменит был своим умением спорить А.С. Хомяков. Его любовь к словопрениям стала притчей во языцех. Это было причиной того, что публицистическая пассивность славянофилов в начале сороковых годов многие исследователи объясняют изначальным настроем Хомякова и его сторонников на словесные баталии. Так, П.Ф. Пирожкова пишет: «Время с 1839 по 1845 гг. они (славянофилы - прим. И. Л.) посвятили устному «воспитанию общества», которое было продолжено и в последующие годы» $[12$, с.23]. Сама эта идея «задержала журнально-издательскую деятельность славянофилов» [12, с.24].

В этом вопросе мы не можем согласиться с выдающейся отечественной исследовательницей славянофильства. Слова Хомякова в этом случае опровергаются его делами. А.С. Хомяков, несмотря на то что предпочитал устное слово письменному, периодически писал статьи. Причем не просто статьи, а такие, в которых высказывал и развивал типично славянофильские представления или отвечал на публикации западников. Это мы можем наблюдать уже после публикации «Философического письма» П.Я. Чаадаева. Сразу после его выхода в свет Хомяков написал ответ на это печально знаменитое «Письмо...» [21, с.449-456]. Ответ этот по цензурным соображениям напечатан не был: власти решили предать «Философическое письмо» забвению и даже критические статьи в адрес Чаадаева в печать не пропускать. До 1845 года, когда «Москвитянин» ненадолго перешел в руки славянофилов, Хомяковым было опубликовано четыре статьи в «Москвитянине» $[18,19,20,22]$, а кроме статей множество стихотворений. И помимо статей, увидевших свет на страницах «Москвитянина», Хомяков писал работы, ходившие «по рукам» в рукописях. 
Таким образом, мы видим, что Хомяков в наиболее горячий период своей устной проповеди славянофильства не избегал и писания статей. Но писал и публиковался он редко. Объяснением этому служит версия о неспособности старших славянофилов к систематическому публицистическому и издательскому труду. Именно поэтому славянофилы писали и публиковались редко (во многом поэтому; не стоит забывать о цензуре, которая часто не пропускала сочинения «московской партии»).

«Изустное» распространение своих взглядов во время вечеров, приемов и дружеских встреч стало в кон. 1830-х - нач. 1840-х гг. главным источником проповеди славянофильства. Естественно, не только славянофилы использовали эту форму распространения своих идей. Западники также активно осваивали эту модель распространения своих взглядов.

Другой «непечатной» формой популяризации своих взглядов стало для славянофилов распространение рукописных статей. Это, естественно, не было новшеством в Москве XIX в. Философские статьи и художественные произведения ходили в списках по Москве и в XVIII, и в XIX, и, как известно, даже в XX в. Такой «самиздат» использовался и славянофилами. В 1839 г. Хомяков написал статью «О старом и новом» [23, с.11-30], с написанием которой связывается появление славянофильства. Вскоре И.В. Киреевский ответил на статью Хомякова [8, 109-121]. Ответ этот, конечно, тоже распространялась в рукописной форме.

Но самым, наверное, известным и скандальным примером славянофильского «самиздата» были «Письма из Риги» Ю.Ф. Самарина [3, 163]. В своих «Письмах...» Самарин критикует политику Российской империи в Прибалтике, засилье немцев, угнетенное положение туземного элемента. Не имея возможности опубликовать свой труд, Самарин приложил все усилия, чтобы распространить его в списках и привлечь как можно большее общественное внимание к проблемам прибалтийских крестьян. Даже не опубликованные в журналах «Письма из Риги» привлекли внимание цензуры и тайной полиции. Самарин был арестован. Николай I лично выразил ему неудовольствие за его статьи.

Интересно, что впоследствии, уже в годы правления Александра II, Самарин в течение нескольких лет печатал за границей продолжение «Писем из Риги». «Окраины России» - так озаглавил Самарин продолжение «Писем...»- продолжали исследование вопроса о положении прибалтийских крестьян и их притеснении со стороны остзейских немцев. «Окраины России» вызвали не меньший резонанс, чем в сове время «Письма из Риги» [14, с.130-150].

Переписывание и распространение публицистики и художественных произведений в первой половине XIX в. было для России нормой. Переписывались стихи, памфлеты и даже целые пьесы. Так, «Горе от ума» Грибоедова впервые увидело свет именно в качестве «самиздата».

Естественно, западники не остались в стороне от такого вида публицистической активности. Еще до появления «О старом и новом» по Москве в списках ходили «Философические письма» Чаадаева. Примечательны здесь два момента. Первый - личность одного из самых преданных «полиграфистов» Чаадаева. Многие списки «Философических писем» были переписаны М.В. Киреевской. Мария Васильевна Киреевская - сестра славянофилов И.В. и П.В. Киреевских - была горячей поклонницей Чаадаева. В первую очередь, поклонницей его личности, а не учения. Это интересный факт прекрасно иллюстрирует положение дел у враждующих партий. Несмотря на идеологический антагонизм, славянофилы и западники принадлежали к одному дворянско-консервативному общественному кругу и философские противоречия никак не могли помешать их личному общению и даже дружбе. По крайней мере, такая ситуация сохранялась до сер. 1840-х гг.

Интересно отметить еще одну особенность русского общества николаевской эпохи, связанную с фактом существования рукописного варианта «Философических писем». Как известно, публикация первого из восьми «Писем...» в журнале «Телескоп» вызвала широкую общественную реакцию и стала главным литературным событием эпохи. Автор «Писем...» подвергся преследованиям. Сначала Чаадаев прошел через ряд допросов, потом был объявлен сумасшедшим. Редактор «Телескопа» Н.И. Надеждин был отправлен в ссылку в Усть-Сысольск, а сам журнал закрыт. Герцен сравнивал появление «Философического письма» в печати с «выстрелом в темную ночь» [5, с.139]. Одним словом, такого резонанса как от публикации статьи Чаадаева до этого российская пресса не знала. Но интересен не сам резонанс от чаадаевского произведения, а то, что «Философические письма» были написаны в начале тридцатых годов и к моменту публикации (1836 г.) идеи Чаадаева были известны всей образованной Москве. Но именно появление их в печати вызвало небывалый резонанс. Это показывает, насколько важным в период правления Николая I было иметь возможность публиковаться. Опубликованная статья вызывала в разы больший эффект, чем распространявшаяся в списках. Это еще раз показывает, в насколько более выгодном положении находились по сравнению со славянофилами западники, у которых были собственные печатные органы.

Наконец, помимо салонной полемики, журнальных публикаций и распространявшегося в рукописной форме «самиздата» существовала еще одна форма обмена мнениями между славянофилами и западниками. Мы на- 
зываем ее «смешанной». Это те случаи, когда на опубликованную работу пишется возражение, но за неимением возможности публикации, статья остается и получает распространение в рукописной форме. Таких примеров в 1830-50-х гг. мы видим много.

Первый пример такой «смешанной полемики» - уже упоминавшийся ответ Хомякова на «Философическое письмо» П.Я. Чаадаева. Другим, более ярким и интересным примером «смешанной полемики» является ряд статей, написанных представителями разных философских течений сороковых годов в 1842 г. Началом этой «смешанной полемики» стала опубликованная в «Москвитянине» Хомяковым статья «О сельских условиях». Как уже упоминалось, на нее последовал ответ от редакции журнала. Здесь против Хомякова выступили уже представители «теории официальной народности», рупором которой был «Москвитянин». Но уже в следующем номере в разделе «Антикритика» появился ответ Хомякова на статью редакции. Здесь мы видим столкновение, хотя и мирное, представителей консервативного крыла русской общественной мысли. Но самое интересное, что в том же 1842 г. ответ на статью Хомякова «О сельских условиях» написал П.Я. Чаадаев [24, с. 539-546]. Естественно, Чаадаев не мог отдать ее ни в один журнал. После появления «Философических писем» ему был закрыт доступ к любой официальной публицистической деятельности. Поэтому Чаадаев писал свой ответ на статью Хомякова, не имея никакой надежды на размещение своей работы в печатных СМИ. Но он считал этот способ активности вполне уместным и действенным для того, чтобы высказать свои контраргументы на статью Хомякова.

Таким образом, мы можем сделать вывод, что славянофилы использовали для распространения и популяризации своих взглядов несколько «непечатных» форм:

1. форма устного диспута;

2. распространение своих произведений в рукописной форме;

3. форма «смешанной полемики», когда на опубликованное произведение приходилось отвечать рукописями.

В освоении всех этих форм славянофилы не были первопроходцами. Не менее активно все эти способы использовали и западники. Несмотря на то, что западники, в отличие от адептов славянофильства, имели собственные печатные органы, николаевская цензура не давал возможности говорить «в полный голос» и волей неволей и той, и другой из враждующих направлений приходилось пользоваться намного менее эффективными по сравнению с печатью способами проповеди своих взглядов. Это не могло не сказаться негативно на развитии русской философии и общественной мысли. Основной вопрос русской философии, «Великий спор» сороковых годов, дал лишь эпизодические примеры философской полемики. Цензурная политика Николая I не давала возможности общественно-политическому противостоянию двух философских течений перерасти в широкую публицистическую полемику.

\section{ЛИТЕРАТУРА}

1. Валицкий А.В кругу консервативной утопии. Структура и метаморфозы русского славянофильства / Анджей Валицкий, пер. с польск. К. Душенко. М.: Новое литературное обозрение, 2019. - 704 с. (Серия Historia Rossica).

2. Виноградов И.А. Гоголь и западное славянофильство: к постановке проблемы // Studia Litterarum. 2017. №4. С.182-207.

3. Виноградов И.А. Славянофильство и западничество в споре о поэме Н.В. Гоголя «Мертвые души»: невостребованное и забытое // Два века. 2020 . №1. C.62-15.

4. Виноградов И.А. Феномен западничества в славянофильстве: взгляд Гоголя // Литературный факт. 2019. №2 (12). С.189-224.

5. Герцен А.И. Былое и думы. - Собрание сочинений в 30 томах, т. ІХ. М., Изд-во АН СССР, 1956. Т.9.

6. Дементьев А.Г. Очерки по истории русской журналистики. 1840-1850 гг. / А.Г. Дементьев. - Москва; Ленинград: Гос. изд-во художественной литературы, 1951. $-500 \mathrm{c}$.

7. Есин Б.И. История русской журналистики (1703-1917) в кратком изложении: Учеб. пособие по специальности 021400 - Журналистика / Б.И. Есин. М.: Флинта: Наука, 2000. - 100, [2] с.

8. Киреевский И.В. Полное собрание сочинений И.В. Киреевского: В 2 т. / Под ред. [и с предисл.] М. Гершензона. Т. 1 - Москва: Путь, 1911.

9. Московский сборник: [т. 1, 2] / подгот. В.Н. Греков. - Санкт-Петербург: Наука, 2014. - 1307 с.

10. Ответ на статью А. Хомякова «0 сельских условиях» // Москвитянин. 1842. IV. С.376-382.

11. Очерки по истории русской журналистики и критики / [редкол.: проф. В.Е. Евгеньев-Максимов и др.]; Ленинградский гос. ун-т им. А.А. Жданова, Филологический ин-т. - Ленинград: Изд-во Ленинградского гос. ун-та им. А.А. Жданова, 1950-1965. - 2 т. Т.1.

12. Пирожкова Т.Ф. Славянофилы и славянофильская журналистика: 1840-1850 гг.: автореферат дис. ... доктора филологических наук: 10.01 .10 / Моск. гос. ун-т им. М.В. Ломоносова. - Москва, 2000. - 85 с.

13. Пирожкова Т.Ф. Славянофильская журналистика / Т.Ф. Пирожкова. - Москва: Изд-во Моск. ун-та, 1997. - 218 с.

14. Пирожкова Т.Ф. «Ттрашная книга» Ю.Ф. Самарина («Окраины России» в восприятии современников) // Вестник Московского университета. Серия 10. 
Журналистика. 2017. №3. С.130-150.

15. Рублева Л.И. История отечественной журналистики XVIII-XIX веков: учебное пособие / Л.И. Рублева. - Южно Сахалинск: изд-во СахГУ, 2012 - 328 с.

16. Самарина Ю.Ф. «0 мнениях «Современника» литературных и исторических» // Москвитянин. 1847. ІІ. С.133-222.

17. Самарин Ю.Ф. Сочинения Ю. Ф. Самарина. - Москва: Д. Самарин, 1877-1911. Т.7.

18. Хомякова А.С. Еще о сельских условиях. Москвитянин. 1842. V. С.512-522.

19. Хомякова А.С. Опера Глинки: Жизнь за царя. Москвитянин. 1844. III. С.68.

20. Хомякова А.С. «0 сельских условиях» // Москвитянин. 1842. III. С.293.

21. Хомякова А.С. Сочинения в двух томах. М.: Московский философский фонд Издательство "Медиум", 1994.- $591+479$ с.

22. Хомякова А.С. Письмо в Петербург о выставке // Москвитянин. 1843. IV. С.211-222.

23. Хомяков А.С. Полное собрание сочинений. Т.З. М.: 1900. - 504 с.

24. Чаадаев П.Я. Полное собрание сочинений и избранные письма: В 2 т. — М.: Наука, 1991. — Т. 1. — 798 с.

() Лебедянцев Иван Михайлович (leb1000.mm@yandex.ru).

Журнал «Современная наука: актуальные проблемы теории и практики»

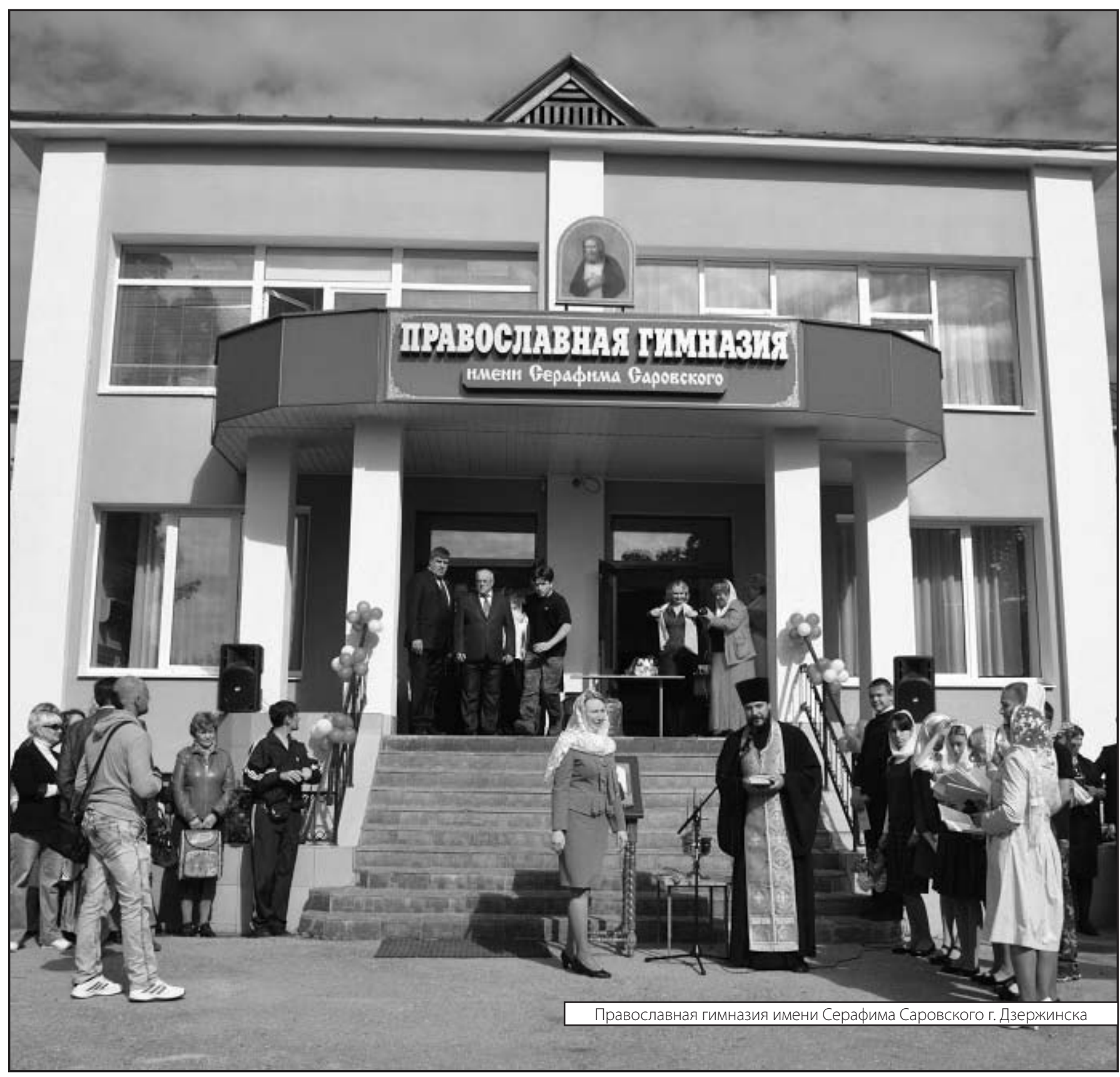

